\title{
Incorporation of Leaf Chemical Constituents into Tobacco Brown Pigments*
}

\author{
by S.J. Sheen
}

Department of Plant Pathology, University of Kentucky, Lexington, Kentucky, U.S.A.

\section{INTRODUCTION}

Wright et al. (18) isolated a dark-brown pigment by acid precipitation of a soluble, non-dialyzable fraction of aged Burley tobacco and characterized it as an ironprotein-chlorogenic acid-rutin complex. The remaining acid-soluble brown pigment of the same non-dialyzable fraction showed a similar qualitative composition. Jacobson (7) reported that brown pigments from a Connecticut shade tobacco were also composed of proteins and polyphenols. $\mathrm{He}$ substantiated this conclusion by incorporating ${ }^{14} \mathrm{C}$-chlorogenic acid and rutin into the pigments in excised leaves. The chemical composition of tobacco brown pigment is further complicated by the presence of alkaloids, pyridine derivatives, carbohydrates, a silicon and possibly other leaf constituents (5). Brown pigments determine the color of cured leaves which has been established as an important criterion of tobacco quality. Recently, they have been implicated as the possible precursors of tumorigenic agents in cigarette smoke (3). The quantitative and qualitative modification of brown pigments may provide a means to minimize smoking hazards without sacrificing leaf color quality. To achieve this goal, the relation of polyphenol and protein content with the amount and kind of brown pigments should be investigated.

Chlorogenic acid (3-O-caffeoylquinic acid) and rutin (quercetin-3-rhamnosidoglucoside) are the predominant polyphenols in tobacco leaves. These polyphenols in green leaves are quantitatively correlated with brown pigments in air-cured products (16). The formation of brown pigments is attributed to the oxidation of polyphenols by chlorogenic acid oxidase (CAO) and peroxidase (PRO) during leaf senescence and curing. Inhibition of these oxidases resulted in a decreased amount of brown pigments (14). It has been suggested that both oxidases may become the protein moiety of the pigments $(13,17)$. However, a recent study revealed that the amino acid composition in acid hydrolysates of the acidprecipitated, alcohol-insoluble brown pigments from both air-cured and flue-cured leaves resembles that of Fraction I protein in tobacco (15). The latter degrades rapidly during the early phase of leaf curing (8). Little information is available concerning the incorporation of Fraction I protein, oxidases and polyphenols into brown

- Received for publication: 3rd October, 1977. pigments. Such information would give insights on the precursor-product relationship that may be used as a guide-line for quantitative and qualitative modifications of brown pigments in cured tobacco. In vivo studies of interactions among leaf constituents as they relate to the formation of brown pigments are not possible. The present study applied in vitro synthesis of brown pigments using varying quantities of ${ }^{14} \mathrm{C}$-labeled polyphenols and proteins in order to determine the percent incorporation of these compounds into the pigments.

\section{MATERIALS AND METHODS}

Different plant parts of tobacco, Nicotiana tabacum cv. Burley 21, were the source of isotope-labeled leaf constituents used in the in vitro synthesis of brown pigments. ${ }^{14} \mathrm{C}$-Chlorogenic acid was produced from green capsules which were longitudinally split and incubated in Petri dishes in darkness for 24 hours at ambient temperatures with $5 \mathrm{ml}$ of $20 \mathrm{mM}$ phosphate buffer, $\mathrm{pH} 6.5$, containing L-phenylalanine- $\mu-14 \mathrm{C}\left(3.1 \times 10^{-6} \mathrm{cpm}\right), 50$ $\mathrm{mM}$ quinic acid, $50 \mathrm{mM} \mathrm{KCl}$ and $25 \mu \mathrm{g}$ neomycin. Purification of ${ }^{14} \mathrm{C}$-chlorogenic acid employed Soxhlet extraction in $80 \%$ isopropanol, gel filtration with Sephadex LH-20 and two-dimensional paper chromatography as the procedures described in a previous paper (12). ${ }^{14} \mathrm{C}$-Chlorogenic acid so isolated excluded the isomers 4- and 5-caffeoylquinic acids and had UV spectra superimposable with that of authentic compound. Its specific radioactivity was $2.7 \times 10^{-6} \mathrm{cpm} / \mathrm{mmol}$.

Burley 21 seedlings grown in hydroponic culture were used for production of ${ }^{14} \mathrm{C}-\mathrm{CAO}$ and ${ }^{14} \mathrm{C}-\mathrm{PRO}$. The plants were kept in a growth chamber where temperatures were maintained at $80^{\circ} \mathrm{C}$ during a 14-hour day and $65^{\circ} \mathrm{C}$ at night. At the 5-6 leaf stage, the seedlings were transferred into aluminum-foil-covered beakers $(250 \mathrm{ml})$ filled with Hoagland solution just enough to submerge the roots and were sprayed with $1000 \mathrm{ppm}$ of Ethrel, an ethylene-releasing agent, in $0.1 \%$ Tween 80 solution. ${ }^{14} \mathrm{C}$-Amino acids in $0.1 \mathrm{M}$ sodium phosphate buffer, $\mathrm{pH} 7$, were added into the beakers in an amount of $2 \mu \mathrm{Ci}$ per plant. Ethrel applications were repeated daily and, whenever needed, Hoagland solution was added to maintain the moist condition of the roots. On the fifth day, the leaves beginning to yellow were harvested and ground in cold acetone $\left(-40^{\circ} \mathrm{C}\right)$ con- 
taining $0.8 \mathrm{mM} 2$-mercapto-ethanol to make an acetone powder. The CAO and PRO were partially purified from acetone powder extract by saturation with $35 \%$ and $70 \%$ ammonium sulfate as previously described (10). The specific radioactivities of ${ }^{14} \mathrm{C}-\mathrm{CAO}$ and ${ }^{14} \mathrm{C}$ PRO were $74 \times 10^{-3}$ and $35 \times 10^{-3} \mathrm{cpm} / \mathrm{mg}$ protein, respectively.

For production of ${ }^{14} \mathrm{C}$-Fraction I protein, a ${ }^{14} \mathrm{C}$-amino acid feeding experiment identical to the one described above was carried out except that Ethrel was not used and the seedlings were harvested on the third day after treatment. Fraction I protein was purified into a crystalline form by the method of Chan et al. (1). The specific radioactivity of the Fraction I protein was $32 \times 10^{-6}$ $\mathrm{cpm} / \mu \mathrm{mol}$.

In vitro synthesis of brown pigments was performed in $40 \mathrm{ml}$ of $0.1 \mathrm{M}$ sodium phosphate buffer, $\mathrm{pH} \mathrm{6}$, containing varying quantities of chlorogenic acid and $\mathrm{CAO}$ or PRO with or without radioactivity. Non-radioactive CAO and PRO were prepared from the acetone powder of mature field-grown Burley 21 leaves in the same manner as the afore-mentioned procedures for partial purification of ${ }^{14} \mathrm{C}$-oxidases. Rutin (10 $\mathrm{mg}$ in ethanol) was added to all reaction mixtures and, in the case of PRO reaction, $100 \mu \mathrm{mol}$ of $\mathrm{H}_{2} \mathrm{O}_{2}$ was also added. The reaction mixtures were gently shaken for one hour at ambient temperatures. To isolate the brown pigments, the reaction mixtures were adjusted to $\mathrm{pH} 10$ with $\mathrm{NH}_{4} \mathrm{OH}$ and subsequently acidified to $\mathrm{pH} 1$ with concentrated $\mathrm{H}_{2} \mathrm{SO}_{4}$. The brown pigments precipitated by this procedure are acid-insoluble and those remaining in the solution are acid-soluble. The acid-insoluble pigments were solublized in dilute $\mathrm{NH}_{4} \mathrm{OH}$ solution, $\mathrm{pH} 10$. Both acid-soluble and acid-precipitated pigment solutions were dialyzed in dialyzing tubing with several dhanges of deionized water. The non-dialyzable fractions were freeze-dried and dissolved into $10 \mathrm{ml}$ of dilute $\mathrm{NH}_{4} \mathrm{OH}$, $\mathrm{pH} \mathrm{10}$, for spectrophotometric determination of browning intensity at $420 \mathrm{~nm}$. Aliquots were pipetted into scintillation vials, mixed with $15 \mathrm{ml}$ of Instagel, and radioactivities were counted in a Padkard Automatic Tri-Carb liquid scintillation spectrometer (Model 4322) at $6{ }^{\circ} \mathrm{C}$. A quenching curve based on a dilution series of brown pigments was used to correct quenching effect.

The same two brown pigment fractions were also isolated from air-cured Burley 21 leaves. Their gel permeation profiles were compared with those of the in vitro synthesized pigment fractions. Gel permeation studies employed a Sephadex G-100 column $(1 \times 75 \mathrm{~cm})$ equilibrated with dilute $\mathrm{NH}_{4} \mathrm{OH}$ solution, $\mathrm{pH} 10$. Five milligrams of the pigments was dissolved in $1 \mathrm{ml}$ of the elution solution and passed through the column at a flow rate of $40 \mathrm{ml}$ per hour. Eluates were monitored for pigment distribution with an UV analyzer at $280 \mathrm{~nm}$ and collected in $5 \mathrm{ml}$ fractions whose browning intensity was spectrophotometrically measured at $420 \mathrm{~nm}$. A molecular weight series of proteins (aldolase, ovalbumin, dhymotrypsinogen $A$ and ribonuclease $A$ ) were chromatographed using the same procedure in order to estimate the molecular weight distribution of the pigment fraction.

Under electrophoresis in a polyacrylamide gel with a discontinuous buffer system, the non-dialyzable brown pigments appeared to have at least one major band migrating at the same rate as the indicator dye, bromophenol blue. The in vitro synthesized ${ }^{14} \mathrm{C}$-brown pigments were applied onto a $7.5 \%$ polyacrylamide gel containing $0.3 \% \quad \mathrm{~N}, \mathrm{~N}$-diallyltartardiamide. Disc electrophoresis with Tris-glycine buffer, $\mathrm{pH} 8$, was the method of Davis (4). After the completion of electrophoresis, the gel was sliced into $1 \mathrm{~mm}$ sections and solublized in $1 \mathrm{ml}$ of $2 \%$ periodic acid. Radioactivity was counted by the foregoing procedure, and the percent incorporation of radioactivity into the major brown pigment band was calculated.

In certain experiments, the quantity of dilorogenic acid and rutin and the activity and isozymes of $\mathrm{CAO}$ and PRO in the reaction mixtures before and after the in vitro synthesis of brown pigments were determined. Polyphenol quantification was determined by two-dimensional paper chromatography and spectrophotometry, whereas oxidase assays employed spectrophotometric, electrophoretic and histochemical methods. Detailed procedures of these analyses have been described elsewhere (12).

\section{RESULTS AND DISCUSSION}

The CAO and PRO preparations from mature Burley 21 leaves exhibited $0.9(\Delta \mathrm{A} / \mathrm{mg} / \mathrm{min})$ and $12.76(\Delta \mathrm{A} /$ $100 \mu \mathrm{g} / \mathrm{min}$ ) activities, respectively. The CAO activity in the PRO preparation was negligible. Conversely, PRO activity in the CAO fraction was less than $15 \%$ of that in the PRO fraction. The addition of $\mathrm{CAO}$ into the reaction mixture containing chlorogenic acid and rutin changed the solution instantaneously from a light yellow into a dark brown color, whereas a similar change of coloration in the PRO catalyzed solution occurred only in the presence of $\mathrm{H}_{2} \mathrm{O}_{2}$. In either case, there was no formation of brown substances in the absence of polyphenols or oxidases. This confirms a general belief that enzymatic oxidation of polyphenols is the process of brown pigment formation. Reaction mixtures containing more than $1 \mathrm{mg}$ CAO or PKO per milliliter were assayed for oxidase activity after the completion of in vitro synthesis of the brown pigments. Oxidase activity was not measurable in either case. Neither the CAO nor the PRO isozymes were detected after disc gel electrophoresis. In contrast, the reaction mixtures devoid of chlorogenic acid and rutin showed a slightly yellow coloration and retained oxidase and isozyme activity after one hour of shaking. These results support the previous conclusions that polyphenoloxidase and PRO are the protein moiety of tobacco brown pigments (13, 17). This was further substantiated by the recovery of about $0.06 \%$ of total PRO activities in the acid-soluble brown pigments synthesized in vitro; however, there was no measurable activity in the acid-precipitated fraction. 
Figure 1. Cel permeation chromatographic proflles of acid-precipitated and acld-soluble, non-dialyzable brown plgments from alr-cured Burley 21 leaves. Chromatographic conditions are detailed in Materials and Methods.
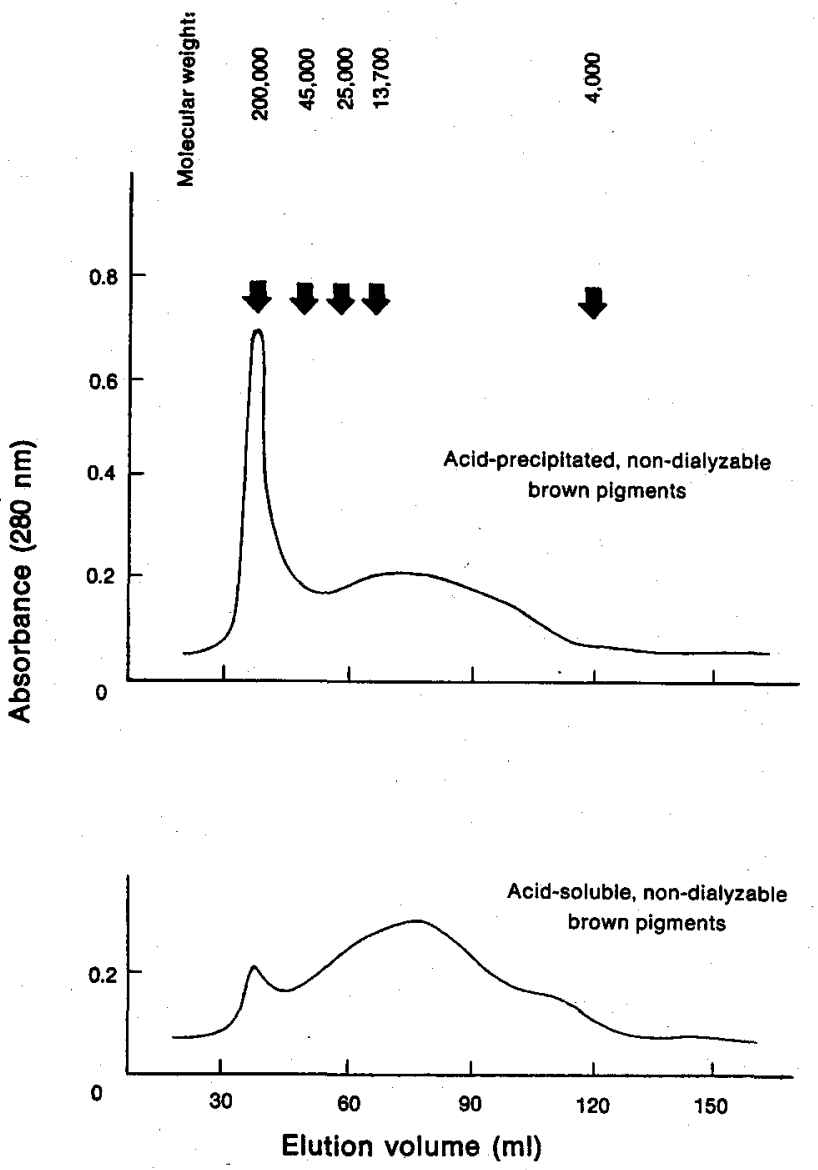

The amount of residual activity reflects nearly total inactivation of PRO. Both brown pigment fractions exhibited no CAO activity.
Figure 1 shows the differences in molecular weight distribution between acid-precipitated and acid-soluble brown pigments as resolved by gel permeation chromatography. In comparison of the same pigment fractions from air-cured leaf and in vitro synthesis with $\mathrm{CAO}$ or PRO, a difference was not apparent. In general, the acidprecipitated pigments contained an absorption peak at the solvent front which was accompanied by an intense brown coloration. This was followed by a broad distribution of absorbents with a yellow color. These absorbents must represent the aggregates of proteins and polyphenols. According to Chortyk (2), the major portion of the acid-precipitated brown pigments was in the $10,000-60,000$ range of molecular weight. This may correspond to the protein distribution but does not coincide with the browning intensity. Whether the latter is determined by the nature of protein-polyphenol complex or the amount of polyphenols in the aggregates cannot be elucidated without further fractionation and analysis of the pigments.

The solvent front of the acid-soluble pigments in the gel permeation profile was less conspicuous and exhibited a light yellow color. A large proportion of protein-polyphenol complex appeared in the 8,000-25,000 range of molecular weight along with an intense brown color. When both fractions of brown pigments, isolated either from air-cured leaves or synthesized in vitro, were subjected to disc gel electrophoresis, they showed an identical mobility toward the anode as the indicator, bromophenol blue. This confirms Wright's finding that the pigments are negatively charged (18). The foregoing physiochemical properties assure that the acid-precipitated and acid-soluble brown pigments synthesized in vitro by the present method are similar to those isolated from aircured Burley leaves. Brown pigments are also known to be present in the dialyzable fraction of leaf extract (19).

Table 1. In vitro Incorporation of ${ }^{14} \mathrm{C}$-chlorogenic acld Into tobacco brown plgment fractions.

\begin{tabular}{|c|c|c|c|c|c|c|c|c|c|}
\hline \multirow[b]{2}{*}{$\begin{array}{c}\text { Oxidase } \\
\text { (10 mg) }\end{array}$} & \multirow[b]{2}{*}{$\begin{array}{c}{ }^{\text {"C-Chloro- }} \\
\text { genic acid } \\
\text { (mg) }\end{array}$} & \multicolumn{4}{|c|}{ Acid-precipitated, non-dialyzable fraction } & \multicolumn{4}{|c|}{ Acid-soluble, non-dialyzable fraction } \\
\hline & & $\begin{array}{c}\text { Absorbance } \\
(420 \mathrm{~nm})\end{array}$ & $\begin{array}{c}{ }^{14} \mathrm{C} \text { Activity } \\
\text { (dpm) }\end{array}$ & $\begin{array}{c}{ }^{14} \mathrm{C} \\
\text { Recovery } \\
(\%)\end{array}$ & $\begin{array}{c}{ }^{14} \mathrm{C} \text { in the } \\
\text { pigment } \\
\text { band } \\
(\%)\end{array}$ & $\begin{array}{c}\text { Absorbance } \\
(420 \mathrm{~nm})\end{array}$ & $\begin{array}{c}{ }^{14} \mathrm{C} \text { Activity } \\
\left(\mathrm{dpm} \times 10^{-3} \text { ) }\right.\end{array}$ & $\begin{array}{c}{ }^{14} \mathrm{C} \\
\text { Recovery } \\
(\%)\end{array}$ & $\begin{array}{c}{ }^{14} \mathrm{C} \text { in the } \\
\text { pigment } \\
\text { band } \\
(\%)\end{array}$ \\
\hline \multirow[t]{6}{*}{ CAO } & 50 & 1.50 & 5033 & 0.42 & 64 & 8.00 & 280 & 23.22 & 97 \\
\hline & 25 & 1.40 & 3161 & 0.52 & 60 & 6.25 & 172 & 28.56 & 91 \\
\hline & 12.5 & 1.37 & 2446 & 0.81 & 48 & 4.95 & 84 & 27.75 & 91 \\
\hline & 6.3 & 1.24 & 1418 & 0.94 & 37 & 4.13 & 46 & 30.28 & 88 \\
\hline & 3.1 & 1.10 & 550 & 0.73 & 24 & 3.38 & 23 & 30.21 & 96 \\
\hline & 0 & 0.82 & - & - & - & 0.35 & - & - & - \\
\hline \multirow[t]{6}{*}{ PRO } & 50 & 1.30 & 950 & 0.08 & 57 & 4.50 & 138 & 11.46 & 98 \\
\hline & 25 & 1.20 & 456 & 0.08 & 46 & 2.45 & 55 & 9.15 & 95 \\
\hline & 12.5 & 0.88 & 461 & 0.15 & 25 & 2.37 & 33 & 10.96 & 93 \\
\hline & 6.3 & 0.92 & 198 & 0.13 & 35 & 1.78 & 20 & 13.04 & 94 \\
\hline & 3.1 & 0.72 & 338 & 0.45 & 22 & 1.60 & 10 & 13.77 & 96 \\
\hline & 0 & 0.24 & - & - & - & 0.28 & - & - & - \\
\hline
\end{tabular}


Table 2. In vitro Incorporation of ${ }^{14} \mathrm{C}$-chlorogenic acid oxidase into tobacco brown plgment fractions.

\begin{tabular}{|c|c|c|c|c|c|c|c|c|c|}
\hline \multirow[b]{2}{*}{$\begin{array}{c}{ }^{14} \mathrm{C}-\mathrm{CAO} \\
\text { (mg) }\end{array}$} & \multirow{2}{*}{$\begin{array}{l}\text { Chloro- } \\
\text { genic } \\
\text { acid } \\
\text { (mg) }\end{array}$} & \multicolumn{4}{|c|}{ Acid-precipitated, non-dialyzable fraction } & \multicolumn{4}{|c|}{ Acid-soluble, non-dialyzable fraction } \\
\hline & & $\begin{array}{l}\text { Absorbance } \\
(420 \mathrm{~nm})\end{array}$ & $\begin{array}{c}{ }^{14} \mathrm{C} \text { Activity } \\
\left(\mathrm{dpm} \times 10^{-3}\right)\end{array}$ & {$\left[\begin{array}{c}{ }^{14} \mathrm{C} \text { Recovery } \\
(\%)\end{array}\right.$} & $\begin{array}{c}{ }^{14} \mathrm{C} \text { in the } \\
\text { pigment } \\
\text { band } \\
(\%)\end{array}$ & $\begin{array}{c}\text { Absorbance } \\
(420 \mathrm{~nm})\end{array}$ & $\begin{array}{l}{ }^{14} \mathrm{C} \text { Activity } \\
\left(\mathrm{dpm} \times 10^{-3} \text { ) }\right.\end{array}$ & $\mid \begin{array}{c}{ }^{14} \mathrm{C} \text { Recovery } \\
(\%)\end{array}$ & $\begin{array}{c}{ }^{14} \mathrm{C} \text { in the } \\
\text { pigment } \\
\text { band } \\
(\%)\end{array}$ \\
\hline
\end{tabular}

\section{Experiment 1}

$50 \quad 50$

1050

$5 \quad 50$

150
4.65

1.30

0.80

0.45

1896
418
160
28

1896

28
51.35

56.53

43.43

38.09
73

84

44

35

10.75
8.10
7.80
3.75

0.75

7.80

3.75
740

142

93

10
20.45

19.16

25.25

13.88
60

58

51

45

\section{Experiment 2}

$\begin{array}{rrrrrrrrrr}10 & 100 & 1.40 & 388 & 52.62 & 83 & 14.10 & 143 & 19.33 \\ 10 & 50 & 1.30 & 418 & 56.53 & 84 & 8.10 & 142 & 19.16 & 58 \\ 10 & 10 & 1.10 & 387 & 52.40 & 80 & 2.35 & 100 & 13.47 & 65 \\ 10 & 5 & 1.05 & 427 & 57.77 & 79 & 1.95 & 103 & 13.91 & 65 \\ 10 & 0 & 0.95 & 400 & 54.21 & 86 & 0.15 & 78 & 10.53 & 57\end{array}$

CAO = chlorogenic acid oxidase

Table 3. In vitro Incorporation of ${ }^{14} \mathrm{C}$-peroxidase into tobacco brown pigment fractlons.

\begin{tabular}{|c|c|c|c|c|c|c|c|c|c|}
\hline \multirow[b]{2}{*}{$\begin{array}{c}{ }^{14} \mathrm{C}-\mathrm{PRO} \\
\text { (mg) }\end{array}$} & \multirow[b]{2}{*}{$\begin{array}{l}\text { Chloro- } \\
\text { genic } \\
\text { acid } \\
\text { (mg) }\end{array}$} & \multicolumn{4}{|c|}{ Acid-precipitated, non-dialyzable fraction } & \multicolumn{4}{|c|}{ Acid-soluble, non-dialyzable fraction } \\
\hline & & $\begin{array}{l}\text { Absorbance } \\
(420 \mathrm{~nm})\end{array}$ & $\begin{array}{c}{ }^{14} \mathrm{C} \text { Activity } \\
\left(\mathrm{dpm} \times 10^{-3}\right)\end{array}$ & $\begin{array}{c}{ }^{14} \mathrm{C} \\
\text { Recovery } \\
(\%)\end{array}$ & $\begin{array}{c}{ }^{14} \mathrm{C} \text { in the } \\
\text { pigment } \\
\text { band } \\
(\%)\end{array}$ & $\begin{array}{c}\text { Absorbance } \\
(420 \mathrm{~nm})\end{array}$ & $\begin{array}{c}{ }^{14} \mathrm{C} \text { Activity } \\
\left(\mathrm{dpm} \times 10^{-3}\right)\end{array}$ & $\begin{array}{c}{ }^{14} \mathrm{C} \\
\text { Recovery } \\
(\%)\end{array}$ & $\begin{array}{c}{ }^{14} \mathrm{C} \text { in the } \\
\text { pigment } \\
\text { band } \\
(\%)\end{array}$ \\
\hline
\end{tabular}

\section{Experiment 1}

$\begin{array}{rrrrrrrrrr}50 & 50 & 1.60 & 658 & 36.97 & 85 & 7.90 & 668 & 37.50 & 50 \\ 10 & 50 & 1.35 & 102 & 28.51 & 75 & 4.80 & 112 & 31.11 & 42 \\ 5 & 50 & 0.80 & 56 & 31.39 & 77 & 4.40 & 53 & 29.78 & 45 \\ 1 & 50 & 0.75 & 13 & 36.88 & 72 & 2.20 & 10 & 27.39 & 55\end{array}$

\section{Experiment 2}

\begin{tabular}{rrrrrrrrrr}
10 & 100 & 3.55 & 117 & 32.92 & 80 & 12.75 & 132 & 37.01 & 50 \\
10 & 50 & 1.35 & 102 & 28.51 & 75 & 4.80 & 112 & 31.11 \\
10 & 10 & 1.30 & 126 & 35.46 & 56 & 1.05 & 105 & 29.49 \\
10 & 5 & 1.30 & 132 & 37.25 & 86 & 0.70 & 90 & 25.14 & 55 \\
10 & 0 & 0.55 & 111 & 31.29 & 72 & 0.55 & 116 & 32.65 & 55 \\
\hline
\end{tabular}

PRO = peroxidase

An intense brown coloration of the dialysate from the reaction mixture is in agreement with the fact that there are low molecular weight polymers containing proteins and/or oxidized polyphenols. Complex polyphenols with a brown appearance have been isolated from cured tobacco (9).

The absorbance of brown color at $420 \mathrm{~nm}$ in both acidprecipitated and acid-soluble brown pigments was positively correlated with the concentration of chlorogenic acid in the reaction mixture (Table 1). This is in keeping with the positive correlation between chlorogenic acid content in green leaves and brown pigment quantity in air-cured tissues (16). Chlorogenic acid concentration in the reaction mixture also determined its amount of incorporation into brown pigments. For the acid-precipi- tated pigments, incorporation appeared more in the CAO-mediated reaction than that treated with PRO. However, there was less than one percent recovery of radioactivity in both cases. When the concentration of chlorogenic acid decreased in the reaction mixture, the percent recovery became higher, but its incorporation into the brown pigment band in the polyacrylamide gel was lower. This indicates that quinones formed from polyphenol oxidation are not randomly complexed with proteins, and its aggregation tends to be in favor of large molecular weight proteins. The incorporation of ${ }^{14} \mathrm{C}$ chlorogenic acid into the acid-soluble brown pigments appeared to be independent of chlorogenic acid concentration, and more than $90 \%$ of the radioactivity was associated with the brown pigment band. On the 
average, about $30 \%$ of ${ }^{14} \mathrm{C}$-chlorogenic acid was recovered in both of the pigment fractions formed by CAO catalysis. In contrast, there was only a $12 \%$ recovery in the PRO-mediated reaction.

A positive correlation between the quantity of chlorogenic acid and the absorbance $(420 \mathrm{~nm})$ of brown pigments also existed in the studies on the in vitro incorporation of ${ }^{14} \mathrm{C}-\mathrm{CAO}$ and ${ }^{14} \mathrm{C}-\mathrm{PRO}$ into brown pigments (Tables 2 and 3). In addition, varying CAO quantity affected the absorbance and the percent incorporation of radioactivity in both acid-precipitated and acid-soluble pigments. The more the $\mathrm{CAO}$ in the reaction mixture, the higher the percentage of radioactivity was in the pigment band. On the other hand, the quantity of chlorogenic acid in the reaction mixture did not alter the percent of CAO incorporation into the precipitated pigments. It did, however, enhance $\mathrm{CAO}$ incorporation into the acid-soluble fraction. In either case, the radioactivity in the pigment band remained relatively constant. Similar patterns of isotope incorporation were evident in the ${ }^{14} \mathrm{C}$-PRO experiments. The exception was that there was less isotope recovery in the acid-precipitated pigments but more in the acid-soluble ones. Overall, $60-70 \%$ of oxidase preparations were recovered in the two pigments, and $50-80 \%$ of this radioactivity can be accounted for in the pigment band. The absence of chlorogenic acid in the reaction mixtures did not lower the percent recovery of radioactivity in the pigments and pigment bands in most cases. From this, one may conclude that the major proportion of the pigments is the degradation of proteins which may or may not be reacted with quinones, the oxidation products of polyphenols.

It is known that $50 \%$ of soluble proteins in tobacco leaves is Fraction $\mathrm{I}$ protein and it is totally degraded during leaf senescence and curing $(6,8)$. The ${ }^{14} \mathrm{C}$-amino acid feeding experiment employing senescent seedling leaves in the present study might result in an incorpor- ation of radioactivity into Fraction I protein in addition to CAO and PRO. To establish the relationship of the oxidase purification procedure with the recovery of Fraction I protein, the crystalline Fraction I protein of Burley 21 was subjected to the same procedures employed for the isolation of CAO and PRO. About $90 \%$ of the Fraction I protein was salted out with $35 \%$ ammonium sulfate saturation. Of this, $60 \%$ was precipitated out as an acid-precipitable fraction. This implies that Fraction I protein and its degradation products are present in the CAO and PRO preparations and, thus, may contribute the protein moiety of brown pigments.

Data on the incorporation of ${ }^{14} \mathrm{C}$-Fraction I protein into brown pigments are given in Table 4. The increased quantity of Fraction I protein slightly enhanced the browning intensity. However, only about $10 \%$ of Fraction I protein was recovered as the acid-precipitated pigment and $50 \%$ of which appeared in the pigment band. The maximal level of incorporation reached only $1-3 \%$ in the acid-soluble pigments. These results may be explained by the fact that proteases in the CAO preparation catalyzed the degradation of Fraction I protein Particularly, the $\mathrm{pH}$ of the reaction mixture is very close to the $\mathrm{pH}$ optimum ( $\mathrm{pH} \mathrm{5.5)}$ ) one protease that reportedly may be related to the catabolism of Fraction I protein (8). Enzymatic degradation of Fraction I protein was less extensive in the PRO mixture where approximately $30 \%$ of the protein was recovered in the acidprecipitated pigments. Similarly, the percent incorporation into the acid-soluble pigments was three times greater in the PRO mixture than in the CAO solution. Most of the radioactivity appeared in the pigment band except for the acid-precipitated pigment from the CAO reaction where the pigment band contained 50-60\% of the total radioactivity. Nevertheless, the appearance of radioactivity in pigment bands provides additional evidence on the degradation of Fraction I protein in the

Table 4. In vitro Incorporation of "4-Fractlon I protein into tobacco brown plgment fractions.

\begin{tabular}{|c|c|c|c|c|c|c|c|c|c|}
\hline \multirow[b]{2}{*}{$\begin{array}{l}\text { Oxidase } \\
(10 \mathrm{mg})\end{array}$} & \multirow{2}{*}{$\begin{array}{c}{ }^{14} \mathrm{C}-\text { Frac- } \\
\text { tion l } \\
\text { protein } \\
(\mu g)\end{array}$} & \multicolumn{4}{|c|}{ Acid-precipitated, non-dialyzable fraction } & \multicolumn{4}{|c|}{ Acid-soluble, non-dlalyzable fraction } \\
\hline & & $\begin{array}{c}\text { Absorbance } \\
(420 \mathrm{~nm})\end{array}$ & 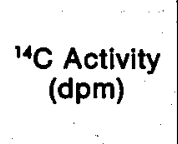 & $\begin{array}{c}{ }^{14} \mathrm{C} \\
\text { Recovery } \\
(\%)\end{array}$ & $\begin{array}{c}{ }^{14} \mathrm{C} \text { in the } \\
\text { pigment } \\
\text { band } \\
(\%)\end{array}$ & $\begin{array}{c}\text { Absorbance } \\
(420 \mathrm{~nm})\end{array}$ & $\begin{array}{l}{ }^{14} \mathrm{C} \text { Activity } \\
\text { (dpm) }\end{array}$ & $\begin{array}{c}{ }^{14} \mathrm{C} \\
\text { Recovery } \\
(\%)\end{array}$ & $\begin{array}{c}{ }^{4} \mathrm{C} \text { in the } \\
\text { pigment } \\
\text { band } \\
(\%)\end{array}$ \\
\hline \multirow[t]{5}{*}{ CAO } & 900 & 4.20 & 6250 & 10.85 & 55 & 11.20 & 1388 & 2.41 & 100 \\
\hline & 450 & 3.50 & 3150 & 10.95 & 51 & 10.80 & 800 & 2.78 & 100 \\
\hline & 150 & 3.05 & 1375 & 14.32 & 56 & 9.91 & 150 & 1.56 & 99 \\
\hline & 50 & 2.90 & 350 & 10.93 & 68 & 8.60 & 50 & 1.56 & 100 \\
\hline & 0 & 1.45 & - & 一 & - & 8.70 & 一 & - & - \\
\hline \multirow[t]{5}{*}{ PRO } & 900 & 3.35 & 11863 & 20.60 & 96 & 6.55 & 1800 & 3.13 & 87 \\
\hline & 450 & 2.15 & 9575 & 33.25 & 71 & 6.15 & 975 & 3.39 & 69 \\
\hline & 150 & 1.83 & 2975 & 30.99 & 90 & 5.15 & 838 & 8.72 & 100 \\
\hline & 50 & 1.29 & 1000 & 31.25 & 80 & 4.95 & 100 & 3.63 & 100 \\
\hline & 0 & 1.28 & - & - & - & 4.95 & - & - & - \\
\hline
\end{tabular}


reaction mixture because this protein is too large to migrate toward the anode through the gel matrix of the present electrophoretic system.

The degradation rate of Fraction I protein may affect the quantity of acid-precipitated and acid-soluble brown pigments. This is evidenced by the previous finding that flue-cured leaves contain more acid-precipitated brown pigment than air-cured tobacco (15). In other words, the curing process plays a major role in determining the quantity and quality of the brown pigments in cured tobacco. The present results also substantiate the previous findings that the concentration of polyphenols, especially chlorogenic acid, determines the extent of leaf browning, and $\mathrm{CAO}$ and $\mathrm{PRO}$ incorporate into the pigment as a result of product inhibition $(13,17)$. Genetic variability in the content of polyphenols and oxidases exists among Nicotiana species and within $N$. tabacum (11.) Therefore, breeding and cultural practices would provide an effective means to modify tobacco leaf qualities that are associated with brown pigments.

The complexity of brown pigments can be further manifested by incorporation of other leaf constituents since alkaloids, pyridine derivatives and carbohydrates have been identified in brown pigments (5). Wright et al. (18) found a large quantity of a polysaccharide in the non-dialyzable fraction of the pigments. Brown pigments synthesized in vitro by the present method may contain glycoproteins but not a polysaccharide per se. This delineates any possible effect of this polysaccharide on the browning reaction on the one hand and on the pyrolytic products of brown pigments on the other. The in vitro synthesis of brown pigments in the present study demonstrated the feasibility of selective labeling of pigment components. This facilitates future research in elucidation of the precursor-product relationship in the tobacco and health related problems, since the pyrolysate of brown pigments contains polynuclear aromatic hydrocarbons and phenols, which are respectively identified as tumor initiators and promoters (20).

\section{SUMMARY}

The percent incorporation of dhorogenic acid, chlorogenic acid oxidase (CAO), peroxidase (PRO) and Fraction I protein into the non-dialyzable fraction of acidprecipitated and acid-soluble brown pigments of tobacco was studied by use of ${ }^{14} \mathrm{C}$-precursors and appropriate substrates in the in vitro synthesis of brown pigments. The in vitro synthesized pigments showed the same gel permeation profiles as the brown pigments isolated from air-cured leaves. The incorporation of chlorogenic acid was correlated with its quantity in the reaction mixture, and a significant amount of incorporation appeared in the acid-soluble pigments which also correlated with browning intensity. The amount of protein fractions containing CAO and PRO affected the percent incorporation of radioactivity, but this was independent of dlorogenic acid concentration. In addition to the loss of CAO and PRO during the formation of brown pigments, the de- gradation of proteins, primarily Fraction I protein, occurred in the reaction mixture. The degradation products of Fraction I protein were recovered in both brown pigments. Results indicate that chlorogenic acid oxidation is the major factor for browning, and the degradation products of Fraction I protein and CAO and PRO contribute to the protein moiety of the pigments.

\section{ZUSAMMENFASSUNG}

Bei der in-vitro-Synthese von braunen Pigmenten wurde unter Verwendung von ${ }^{14} \mathrm{C}$-markierten Vorläufern und geeigneten Substraten untersucht, in welchem Verhältnis Chlorogensäure, Chlorogensäureoxidase (CAO), Peroxidase (PRO) und Fraktion-I-Protein in die nicht dialysierbare Fraktion der säuregefällten und säurelöslichen braunen Pigmente des Tabaks aufgenommen werden. Die in vitro synthetisierten Pigmente zeigten die gleichen GelPermeationsprofile wie die aus nair-cured ${ }^{*}$-Blattabaken gewonnenen braunen Pigmente. Die Inkorporation von Chlorogensäure korrelierte mit deren Gehalt in der Reaktionsmischung, und ein beträchtlicher Teil der aufgenommenen Menge fand sich in den säurelöslichen Pigmenten wieder, die ebenfalls mit der Bräunungsintensität korrelierten. Die Menge der Proteinfraktionen, die Chlorogensäureoxidase und Peroxidase enthielten, beeinflußte die prozentuale Aufnahme von Radioaktivität; dies war jedoch unabhängig von der Chlorogensäurekonzentration. Außer dem Verlust an Chlorogensäureoxidase und Peroxidase während der Bildung von braunen Pigmenten fand in dem Reaktionsgemisch der Abbau von Proteinen, vor allem von Fraktion-I-Protein, statt. Die Abbauprodukte von Fraktion-I-Protein fanden sich in beiden braunen Pigmenten. Aus den Ergebnissen läßt sich schließen, daß die Bräunung hauptsächlich auf der Oxidation der Chlorogensäure beruht und daß die Abbauprodukte des Fraktion-I-Proteins mit Chlorogensäureoxidase und Peroxidase zu dem Proteinanteil in den Pigmenten beitragen.

\section{RESUME}

Le pourcentage d'incorporation d'acide chlorogénique, d'oxidase d'acide dhlorogénique (CAO), de peroxidase $(P R O)$ et de protéines de la fraction I dans la fraction non-dialysable de pigments bruns précipités dans l'acide et de pigments bruns solubles dans l'acide, a été étudié au moyen de précurseurs ${ }^{14} \mathrm{C}$ et de substrats appropriés dans la synthèse in vitro des pigments bruns. Les pigments synthétisés in vitro ont présenté les mêmes profils d'imprégnation du gel que les pigments bruns extraits de feuilles *air-cured*.

On a trouvé une corrélation entre l'incorporation de l'acide chlorogénique et sa concentration dans le mélange de réactifs, et un taux significatif d'incorporation est apparu dans la fraction des pigments solubles dans l'acide qui étaient également en corrélation avec l'inten- 
sité du brunissement. La quantité de fractions protéiques contenant du CAO et du PRO a infuencé le taux d'incorporation de radioactivité, ceci indépendamment de la concentration d'acide dilorogénique. En plus de la perte en CAO et en PRO durant la formation des pigments bruns, les protéines; principalement celles de la fraction I, se sont dégradées dans le mélange de réactifs. Les produits de dégradation des protéines de la fraction I furent retrouvés dans les deux sortes de pigments bruns. Les résultats indiquent que l'oxidation de l'acide chlorogénique est le facteur principal de brunissement et que les produits de dégradation des proteines de la fraction I et le CAO et le PRO contribuent à la formation de la partie protéique des pigments.

\section{REFERENCES}

1. Chan, P. H., K. Sakano, S. Singh and S. G. Wildman: Crystalline Fraction I protein: Preparation in large yield; Science 176 (1972) 1145-1146.

2. Chortyk, O. 'T.: Comparative studies on the brown pigments of tobacco; Tob. Sci. 11 (1967) 137-139.

3. Chortyk, O. T., W. S. Schlotzhaver and R. L. Stedman: Composition studies on tobacco, XXIII. Pyrolytic and structural investigations on the polyphenolamino acid pigments of leaf; Beitr. Tabakforsch. 3 (1966) 422-429.

4. Davis, B. J.: Disc electrophoresis, II. Method and application to serum human protein; N.Y. Acad. Sci. Ann. 121 (1964) 404-427.

5. Dymicky, M., O. T. Chortyk and R. L. Stedman: Composition studies on tobacco, XXVII. Polyphenol-amino acid leaf pigment: further structural investigations; Tob. Sci. 11 (1967) 42-44.

6. Gains, T. P., and J. D. Miles: Protein composition and clássification of tobacco; J. Agric. Food Chem. 23 (1975) 690-694.

7. Jacobson, J. S.: The brown pigments of autolyzed tobacco leaves, I. Isolation and characterization; Arch. Biochem. Biophy. 93 (1961) 580-590.

8. Kawashima, N., and E. Tamaki: Studies on protein metabolism in higher plant leaves, $I$. Amino acid compositions of tobacco leaf proteins at various stages; Phytochem. 6 (1967) 329-338.

9. Runeckles, V. C.: Tobacco polyphenols, IV. A complex polyphenol in flue-cured tobacco; Arch. Biochem. Biophy. 102 (1963) 354-358.

10. Sheen, S. J.: The distribution of polyphenols, dhlorogenic acid oxidase and peroxidase in different plant parts of tobacco, Nicotiana tabacum L.; Phytodhem. 8 (1969) 1839-1847.
11. Sheen, S. J.: Comparative quantities of polyphenols and oxidases in Nicotiana species; Tob. Sci. 14 (1970) 16-19.

12. Sheen, S. J.: Changes in amount of polyphenols and activity of related enzymes during growth of tobacco flower and capsule; Plant Physiol. 51 (1973) 839-844.

13. Sheen, S. J.: Polyphenol oxidation by leaf peroxidases in Nicotiana; Bot. Gazette 135 (1974) 155 to 161.

14. Sheen, S. J.: Quantitative modification of polyphenols and brown pigments by foliar application of certain chemicals in Burley tobacco; Tob. Res. 1 (1975) 59-68.

15. Sheen, S. J., and H. R. Burton: Amino acid composition in tobacco fractions containing brown pigments; J. Ag. Food Chem. 26 (1978) 380-385.

16. Sheen, S. J., C. Grunwald and J. Sims: Effects of nitrogen fertilization and stalk position on poly phenols and carbohydrates in air-cured leaves of three tobacco genotypes; Can. J. Plant Sci. 53 (1973) 897-905.

17. Weybrew, J. A., and R. C. Long: More on tobacco browning: 'The first pigment; Tob. Sci. 14 (1970) 167-169.

18. Wright, H. E., Jr., W. W. Burton and R. C. Berry, Jr.: Soluble browning reaction pigments of aged Burley tobacco, 1. The non-dialyzable fraction; Arch. Biochem. Biophy. 86 (1960) 94-101.

19. Wright, H. E., Jr., W. W. Burton and R. C. Berry, Jr:: Soluble browning reaction pigments of aged Burley tobacco, II. The dialysable fraction; Phytochem. 3 (1964) 525-533.

20. Wynder, E. L., and D. Hoffmann: Tobacco and tobacco smoke, Studies in experimental carcinogenesis; Academic Press, Inc., New York, 1967, p. 730 .

\section{Adknowledgment}

The investigation reported in this paper was in connection with a project of the Kentudey Agricultural Experiment Station, was supported in part by the Kentudey Tobacco Research Board (Project No. KTRB-050) and is published with the approval of the Director as Kentudey Agricultural Experiment Station Journal Series (77-11-145).

\section{Author's address:}

University of Kentucky, College of Agriculture, Dept. of Plant Pathology, Lexington, Kentudey, 40506, U.S.A. 